\title{
A NEW AMERICAN MYRMOSID (HYMENOPTERA: MYRMOSIDAE)
}

\author{
By NEAL A. WEBER \\ Harvard University.
}

The following new species in a small genus of Scoloioid wasps allied to the Mutillidæ is here described in order to use the name in a revision, now in progress, of the ant genus Myrmica Latreille. My thanks are due Professor C. T. Brues and Mr. Richard Dow of Harvard University for their opinions concerning its taxonomic status.

Myrmosa dakotensis n. sp.

Female: Length $3.6 \mathrm{~mm}$.

Color of head blackish brown with a mahogany red transverse band across the base of the mandibles and extending to a level with about the anterior $1 / 4$, of the eyes; of thorax mahogany red with a blackish brown anterior margin on the second segment, extending over the dorsal surface and down to about the middle of the sides, pronotum paler than the second segment; of first abdominal segment and margins of second, mahogany red, other sutures and pygidium duller brown; of appendages mahogany red, heavily infuscated on the apical antennal segments and on the dorsal surfaces of the femora and tibiæ.

Hairs moderately abundant, mostly subappressed and short, except on the abdomen, where longer; joints of flagellum densely and finely pubescent, sparsely and inconspicuously so elsewhere. Posterior metatarsi with long and distinct spines.

Surface of body shining; head densely and coarsely, abdomen less densely and more finely, punctate; dorsal surface of thorax sharply and irregularly vermiculate, irregularly and sharply tuberculate on the propodeum; sides of prono- 
tum striate in a dorso-posterior direction, sides of second segment smooth; propodeum, in dorsal aspect, smooth but for sparse and minute setigerous punctation; first abdominal segment with two sharp, transverse, sinuate carinæ dorso-anteriorly, posteriorly with small tubercles, declivous surface largely smooth, with scattered setigerous punctation; pygidium microscopically punctulate, dull.

Head, in front view, evenly convex posteriorly, a distinct gibbosity in front of the eyes; face with a prominent black spine between the antennæ; ocelli slightly less than $0.04 \mathrm{~mm}$. in diameter, posterior pair $0.22 \mathrm{~mm}$. from each other and $0.31 \mathrm{~mm}$. from the eyes; first segment of the flagellum about as broad as long, equal to the pedicel and shorter than the second. Thorax, in dorsal view, with parallel sides; in lateral view, with a distinct notch between the pronotum and the second segment, humeral angles of the pronotum rounded obliquely, posterior margins forming a rounded right angle, second segment broadly depressed; median ventral gibbosity on the propodeum faint.

Holotype: One female taken by myself at Towner, North Dakota, June 27, 1933.

This species differs distinctly from paratypes of $M$. (Myrmosa) banksi Bradley ${ }^{1}$ in the Museum of Comparative Zoölogy in color, smaller size, larger ocelli and their disposition, less distinct propodeal gibbosity, sculpturing and in other characters. It is much smaller than $M$. thoracica Blake, which is associated by Bradley and Melander with $M$. (Myrmosa) unicolor Say, and differs also in color, sculpturing and shape. From the description of $M$. (Myrmosa) blakei Bradley it differs in smaller size, color, in the shape of humeral angles, smaller ocelli and their disposition and in the presence of distinct posterior metathoracic spines and of dorsal carinæ on the basal abdominal segment.

${ }^{1}$ Bradley, J. C. - Contributions towards a Monograph of the Mutillidae and their Allies of America North of Mexico. IV. A Review of the Myrmosidae. Trans. Amer. Ent. Soc., No. 764, 1917. 
This wasp crawled up on my hand as I was digging up a colony of the ant, Myrmica scabrinodis lobicornis var. fracticornis Emery. The colony was in moist loam under grass roots in a partly shaded situation. The larvæ of the ants were disposed in several chambers scattered through the upper few inches of the soil. It seems possible that this species of Myrmosa parasitizes Myrmica and other ants. 

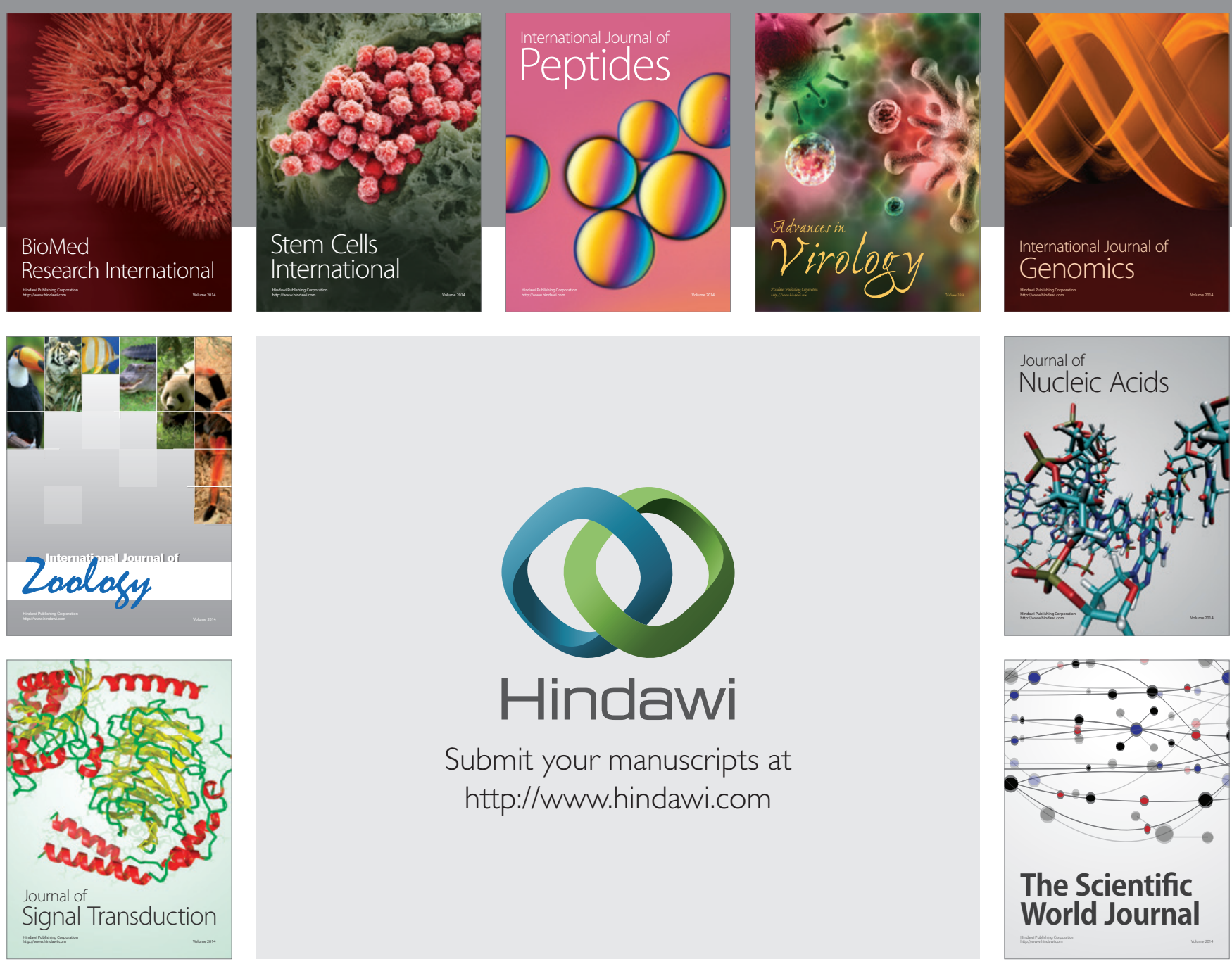

Submit your manuscripts at

http://www.hindawi.com
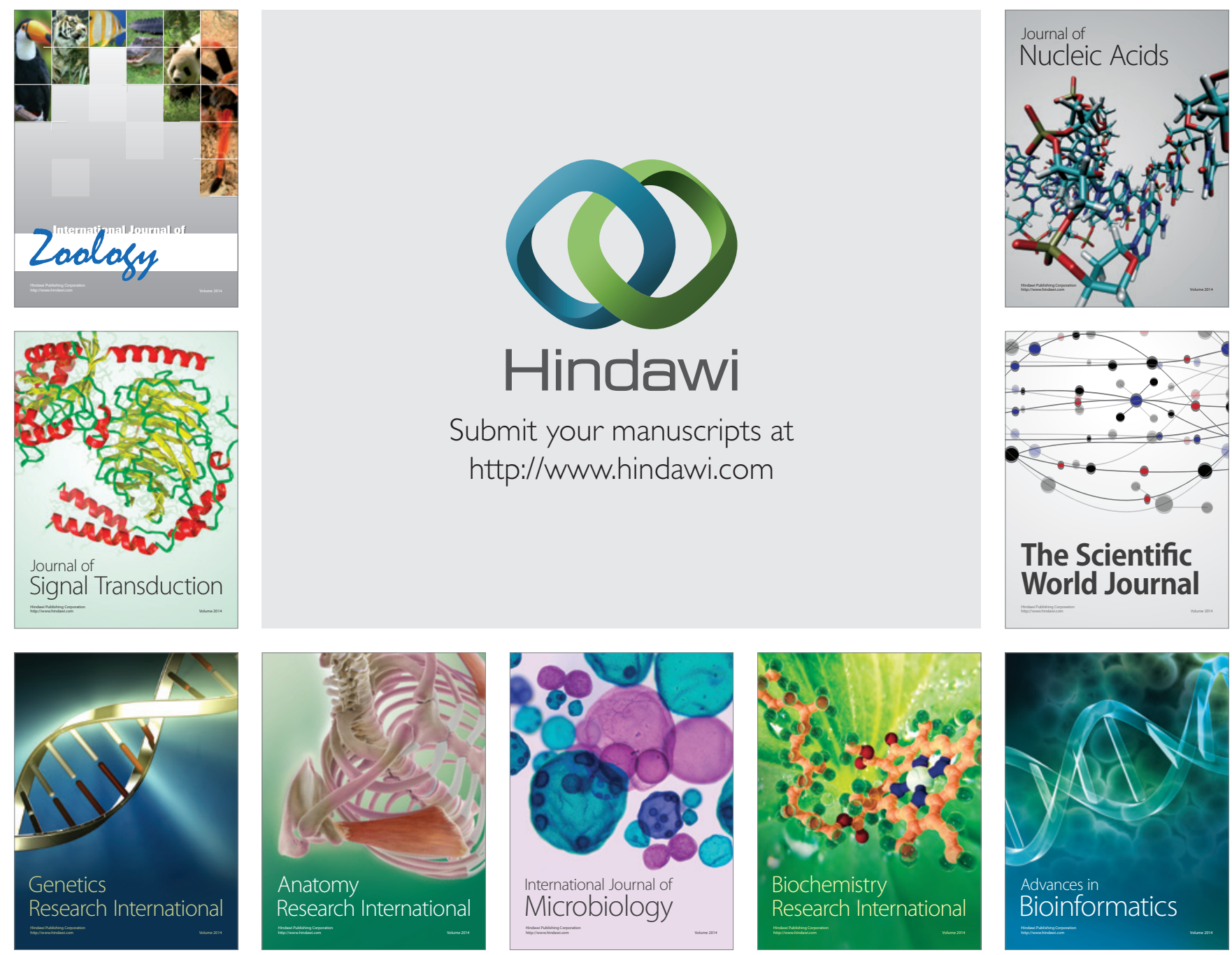

The Scientific World Journal
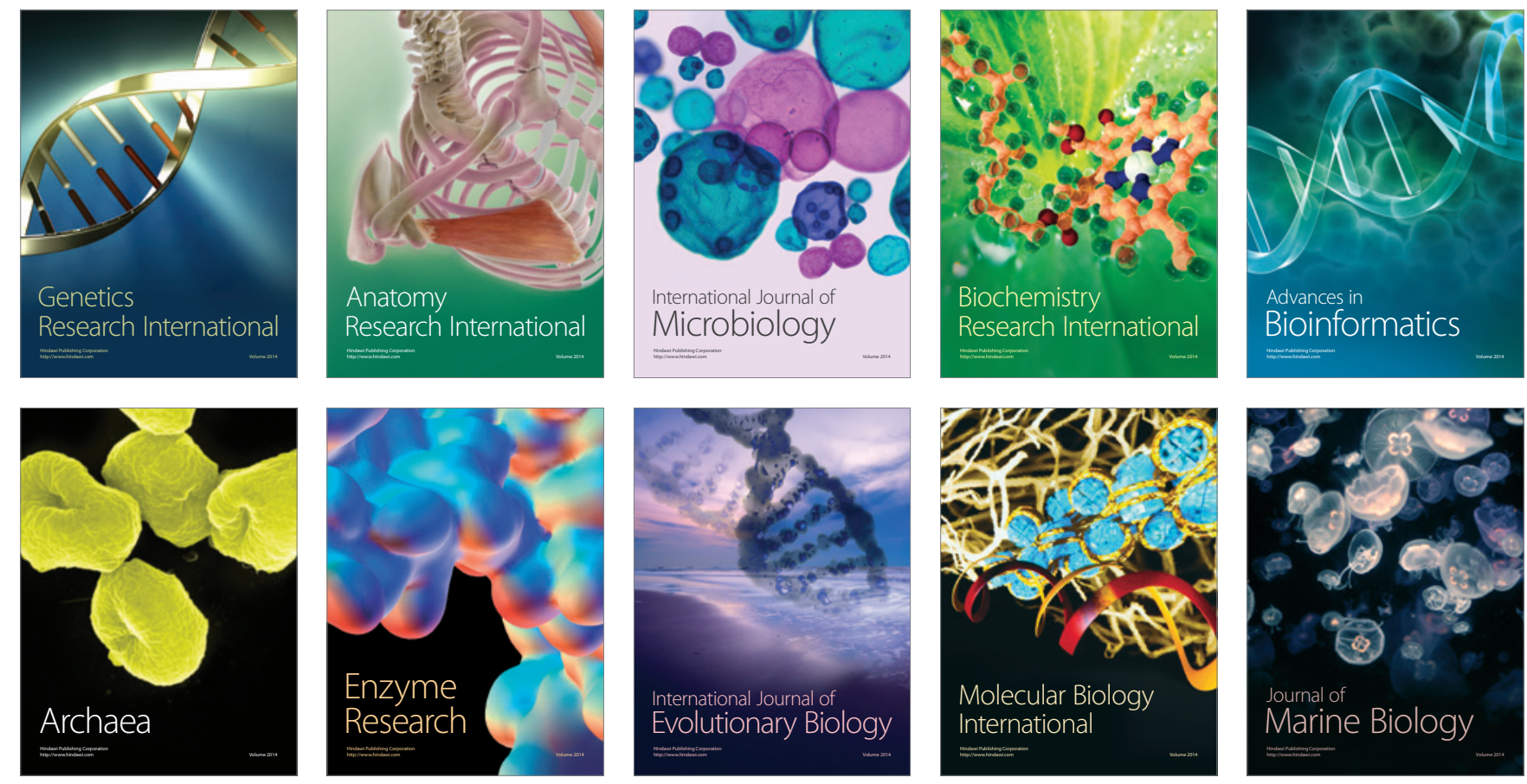